\title{
Somaestetyka tożsamości - między ciałem a słowem
}

Robert Dobrowolski

TEKSTY DRUGIE 2016, NR 5, S. 313-327

DOI: $10.18318 /$ td. 2016.5 .20

W spółcześni kontestatorzy nie podkładają bomb, jeśli już, to specjalizują się w wewnętrznych mikroeksplozjach, rozładowując psychofizyczne napięcie i wybuchając od środka na tyle łagodnie, by nie naruszyć otulających ich tkanek kulturowego organizmu. Te kontrolowane wstrząsy wprawiają $\mathrm{w}$ drżenie ciało społeczne, nie rozrywając jego trzewi, a jedynie poszerzając w nim szczeliny, w których, nie bezboleśnie, ale i z niemałym pożytkiem, pasożytują cyniczni nonkonformiści.

Ten rodzaj zachowawczego sprzeciwu wobec kulturowych ograniczeń dobrze pokazują Idioci Larsa von Triera. W tytułowych bohaterach filmu nie odnajdziemy rozgorączkowanych rewolucjonistów czy też spragnionych krwawej zemsty wykluczonych; ich buntu nie ożywia negatywizm ponurego raskołu. Zadowoleni z siebie „odszczepieńcy", przedrzeźniając, współuczestniczą w społecznych rytuałach, nie rozrywając społecznych więzi, a jedynie rozluźniając dławiący ucisk. Maska błazeńskiej prowokacji skutecznie łagodzi złowrogi grymas bluźnierstwa. Emancypacyjne spazmy „idiotów” to ni mniej, ni więcej - niegroźne dla otoczenia „spastykowanie". W tym
Robert Dobrowolski

- dr, adiunkt W AWF we Wrocławiu. W AWF prowadzi zajęcia z filozofii, świadomości ciała, antropologii filozoficznej; we wrocławskiej ASP - zajęcia z estetyki i psychofizjologii percepcji, a w SWPS we Wrocławiu - zajęcia ze świadomości ciała. Interesuje się estetyką, somaestetyką, psychoanalizą. Kontakt: rdt@wp.pl 
metaforycznym użyciu przez „idiotów” akurat tego neurologicznego terminu odsłania się potrzeba pierwotnego, zmysłowego samopotwierdzenia się, w którym to właśnie swobodnie przeżywające się ciało ma być podstawowym instrumentem odideologizowanej transgresji.

Historia XX-wiecznego eskapizmu obfituje w szaleńcze próby wydobycia z ludzkich trzewi najczystszego źródła Prawdy. Ale i dzisiejsze „spastykowanie", choć wygląda na tym tle całkiem niewinnie, samo nie jest wolne od symptomów dziedzicznego obciążenia i tkwią w nim zalążki niszczącego ekscesu. W każdej chwili transgresywne „spastykowanie” może przemienić się w psychotyczny wybuch. Do tego wątku jeszcze powrócimy. Na chwilę spójrzmy w stronę mrocznych protoplastów.

Wciąż bowiem zagrażają nam podobni do nich Ojcobójcy, którzy głosząc pochwały nieskrępowanego indywidualizmu, wpisują w uległe im podmioty własną wersję „imienia ojca”, i to nie tylko w wymiarze języka, ale i w najgłębszych pokładach bezbronnego ciała.

Przypomnijmy sobie ekscesy akcjonistów wiedeńskich, spektakularnych bluźnierców z drugiej połowy minionego wieku, których wpływy można dostrzec i dziś w wielu przejawach kultury zarówno masowej, jak i wysokiej. Zwłaszcza artystyczny i pozaartystyczny życiorys Otto Muehla dostarcza wymownej ilustracji tego, jak pod pozorem wyzwolenia można sprowadzić nieostrożne indywidua do roli bezwolnych kukieł. Zaczynał on od cielesnych performansów, mających oczyścić ciało z kulturowych inskrypcji, a skończył jako skazany za seksualne przestępstwa, jakich dopuścił się w stworzonych przez siebie sektach. Wszystkie dzieła jego życia zdaje się przenikać wspólny leitmotiv: wyzwolić innych dla Siebie - nowego Ojca. Ta zasada dotyczy też innych karnalnych wyzwolicieli, wprowadzających własny popęd w miejsce przyrzeczonego Absolutu. Jeśli bowiem ktoś wskazuje na możliwość całkowitego wymknięcia się spod władzy dyskursu i schronienia się przed jego prawem w mitycznym utraconym raju Natury, oznacza to, że za tym, który to mówi, przemawia dyskurs nieskrępowanej przemocy. Uwiedzionym niewolnikom mistycznej niemoty pozostaje wtedy tylko milczenie, nieartykułowane oszołomienie i posłuszeństwo wobec tego, do którego należy Słowo.

Nie zaprzeczając potrzebie zyskiwania coraz większej świadomości własnego ciała, a wręcz przeciwnie, podkreślając jeszcze mocniej jej fundamentalne znaczenie dla poszerzenia wolności zarówno indywidualnej, jak i międzyludzkiej, należy zarazem wystrzegać się pokusy budowania odwróconych fantazmatów - zastępowania logosu wzniosłej abstrakcji substancją nieskażonego słowem ciała. 
Istnieje droga omijająca obie pułapki. Wyboista, kręta, ale którą można ostrożnie kroczyć, nie bez uzasadnionej nadziei na postęp. Ścieżki, które do niej tłumnie prowadzą, najwyraźniej zarysowane są w sztuce, tam, gdzie logos odsłania się zawsze jako ucieleśniony.

Do najważniejszych teoretyków, wskazujących na ten obszar możliwych poszukiwań, bez wątpienia należy Julia Kristeva. Według niej ciało nie stanowi ani niewspółmiernej wobec języka rzeczywistości, ani też nie jest pozbawioną znaczenia tabula rasa, całkowicie spenetrowaną przez odgórnie narzucony zapis języka. Kristeva inaczej ustala ich wzajemną relację. To ciało jest podstawowym warunkiem wystąpienia języka, a nie na odwrót, ponieważ zasadnicze mechanizmy sygnifikacyjne uruchamiają się już na poziomie pierwotnych zmysłowych samoidentyfikacji. Tym różni się ona od większości współczesnych psychoanalityków, zarówno zwolenników klasycznego freudyzmu, jak i od lacanowskich reformatorów.

Zgodnie z terminologią Kristevej już w wymiarze semiotycznym, czyli cielesnym, popędowym, afektywnym, nieświadomym, znajdują się zawiązki przyszłych symboli. Pełne wystąpienie tego, co symboliczne, czyli tego, co dąży do jak największej jednoznaczności i zgodności z uznanymi normami i regułami sygnifikacji, nie przynosi ze sobą autentycznego usunięcia z pozornie abstrakcyjnej duchowości znaku jego nieoficjalnego rodowodu. Zmysłowa pamięć zawsze pozostaje w nim żywa. O tym zapomina logocentryczna refleksja i sztuka konceptualna, eliminujące to, co materialne, na rzecz samego tylko pojęcia. We właściwej samorefleksji to, co symboliczne, myśli się w odczuwalnym istnieniu tego, co, ściśle rzecz biorąc - nierefleksyjne. Całkowite wyparcie semiotyczności prowadzi niechybnie do neurotycznego odrealnienia lub schizofrenii.

„Żywe ciało poświęcono pragnieniu, które jest odcięte od ciała. Ciało staje się jedynie znakiem. Kristeva z pasją przekonuje, że gdy język nie jest przesycony popędami, to owo ujarzmienie przez Prawo Znaczącego zamienia żywą osobę w znak, a aktywność sygnifikacyjna zatrzymuje się. Twierdzi ona, że wzorcowy podmiot lacanowskiego pragnienia to nic innego, jak masochistyczny neurotyk pochłonięty samokastracją i okaleczaniem ciała, albo całkowicie katatoniczne ciało klinicznej schizofrenii"1.

Nie mniej niebezpieczne, przed czym również przestrzega Kristeva, byłoby popadnięcie w odwrotną skrajność. „Dla Kristevej zniesienie Symbolicznego

1 K. Oliver Reading Kristeva: Unraveling the Double-bind, przekład własny, Indiana University Press, Bloomington-Indianapolis 1993, s. 33. 
jest zniesieniem społeczeństwa. Bez porządku Symbolicznego żyjemy w stanie delirium lub psychozy"2.

Bezgraniczna symboliczna rozwiązłość, taka, w której nie ma miejsca na żadne tymczasowe silne związanie znaczącego ze znaczonym, rozwiązuje jedynie worek z demonami bełkotliwego popędu.

Między tymi dwiema stronami dialektycznego napięcia, między semiotycznym i symbolicznym otwiera się pole dla estetycznej mediacji, dla dynamicznych, perspektywicznych, niedookreślonych do końca, a więc niezniewalających bez reszty, wyobrażeniowych fantazji. Jak to zauważyła Kristeva, sztuka traktuje fantazję podobnie jak psychoanaliza, dostrzegając w niej wzajemne przenikanie się symbolu i ciała: „[...] według Freuda znaczący jest bezpośrednio ucieleśniony. Jak Proust, Freud jest specjalistą od transsubstancji, z tym że on słyszy ciało w mowie pacjenta opartej na wolnych skojarzeniach, natomiast Proust wpisuje ciało w swoje metafory i hiperboliczne zdania. To zauważalna różnica, ale ich intencja jest analogiczna: poruszyć w słowie wibracje pragnienia. Tym, co, ściśle biorąc, wyłania się na owym skrzyżowaniu, jest fantazja". ${ }^{3} \mathrm{Na}$ tym m.in. polega zadanie sztuki: stwarzać taką przestrzeń dla tego, co symboliczne i tego, co semiotyczne, aby unaocznić ich wzajemny splot, dynamikę niecałościowego pojednania, nieredukcji, żywego współistnienia.

Rehabilitując rolę ciała w nabywaniu samotożsamości, zgadza się jednak bułgarsko-francuska psychoanalityczka z Freudem i Lacanem co do konieczności jakiegoś, choćby bardzo elastycznego symbolicznego regulowania cielesności. Narcystyczna więź z Matką musi zostać zerwana przez symboliczną interwencję Ojca (wspartego przez miłość ojca wyobrażeniowego) i dziecko musi kontynuować swój samoidentyfikacyjny rozwój w konfiguracji trójelementowej czy czteroelementowej, w każdym razie znoszącej narcystycznie zorientowaną dualność. Odstawione od matczynej piersi usta dziecka powinno wypełnić „imię Ojca”, aby mogło stać się symbolicznym ojcowskim pod-miotem wpierw musi wy-miotować matczyne ciało.

"Cielesne wzorce zostają przejęte przez dziedzinę tego, co Symboliczne. Cielesne oddzielenie i odrzucenie może stać się oddzieleniem i odrzuceniem symbolicznym, ponieważ kontrola macierzyńska organizuje psychikę jeszcze przed fazą lustra i edypalnym kryzysem. Macierzyńska kontrola antycypuje

2 Tamże, s. 9.

3 J. Kristeva Intimate Revolt: The Powers and Limits of Psychoanalysis, przekład własny, Columbia University Press, New York 1997, s. 65. 
ojcowski zakaz i edypalne uwikłanie, dzięki którym podmiot ostatecznie wkracza na płaszczyznę sygnifikacji. Dla Kristevej oznacza to, że siła cielesnego popędu zawiera już w samej sobie Symboliczną logikę i moc zakazu oraz że owa popędowa siła nie jest nigdy całkowicie wyparta wewnątrz sygnifikacji"

Ślady tej cielesnosymbolicznej osmozy znajduje Kristeva w sztuce zdolnej do unaocznienia sztuczności konwencjonalnych systemów przedstawień. Estetyczny eksces, rozsadzający symboliczne struktury dzieła, ujawnia cielesność jako możliwość ożywczej zmiany, erupcji, zabezpieczającej przed symbolicznym zeskorupieniem. Ale sztuka pokazuje też drugą stronę medalu: co dzieje się z podmiotem, gdy semiotyczność osiąga poziom skrajnej perwersji lub psychozy. Doświadczenie sztuki stwarza zatem doskonałe warunki dla rozwoju naszej somaestetycznej samoświadomości.„To właśnie z tych powodów Kristeva wydaje się tak zafascynowana awangardowym tekstem, «tekstami» Mallarmégo, Lautréamonta, Artauda, Joyce'a, Schoenberga, Cage'a, Stockhausena, a nawet Giotta i Belliniego"s.

O dziełach sztuki nowoczesnej pisał Adorno: „znamiona rozbicia są dla moderny pieczęcią autentyczności: czymś, co pozwala jej rozpaczliwie negować zamkniętość tego, co zawsze jednakowe; eksplozja jest jednym z jej interwałów"6. Rzeczywiście, w artystycznych dokonaniach awangardy to napięcie między formą i tym, co się jej nie poddaje, jest najdobitniej uwidocznione. To samo jednak dotyczy całej historii sztuki, z wyjątkiem tylko tych dzieł, które na świat przyszły jako martwe płody oschłej emocji i ślepego w swojej zarozumiałości rozumu. Można by dopowiedzieć za Kristevą, że prawda sztuki zawsze odsłania, w mniejszym lub większym stopniu, swoją abiektualną przeszłość.

W tym sensie estetyczne przeżycie to rodzaj kuracji wstrząsowej - jak mówi najczęściej cytowany wers Rilkego - „Piękno to jeno grozy początek". Uważny odbiorca sztuki musi bowiem zmierzyć się z wywołaną w nim świadomością tego, co w nim nieświadome, pretetyczne i cielesne, co zawsze pulsuje w jego egzystencji jako pierwotna energia wzbudzanych w nim i podejmowanych przez niego procesów sygnifikacyjnych.

Fenomenologicznego opisu wzajemnej przekładalności tego, co cielesne, z tym, co symboliczne, w niezwykle przekonywający sposób dokonał

4 K. Oliver Reading Kristeva..., S. 19.

5 E. Grosz Jacques Lacan. A feminist introduction, przekład własny, Routledge, London-New York 1990, S. 152.

6 T.W. Adorno Teoria estetyczna, przeł. K. Krzemieniowa, PWN, Warszawa 1994, s. 44. 
Merleau-Ponty. Jego hiperrefleksja nad tym, co nierefleksyjne w percepcji, ujawniła somatyczne struktury intencjonalności, poprzedzającej i fundującej językową formę aktywności intelektualnej. Ten prymat percepcji wskazuje na fenomenalne, przeżywane ciało jako system ogólnej symboliki i zwornik wszelkiej ekspresji i sensu. Jak słusznie dowodzi Merleau-Ponty, nawet na poziomie odruchów organizmu ludzkie zachowanie nie może zostać zredukowane do schematu działania "bodziec - reakcja”, także tu pozostaje ono znaczącym odniesieniem do środowiska, twórczą odpowiedzią na dany sens konkretnej sytuacji.

„Uporządkowane systematycznie znaki posiadają swoje immanentne znaczenie, które nie powstaje z «Ja myślę», lecz z «Ja potrafię»"7.

Zdaniem francuskiego fenomenologa to nie odizolowany od świata refleksyjny podmiot, lecz aktualnie odczuwane zdolności motoryczne i percepcyjne strukturyzują u podstaw nasze bycie-w-świecie, intendując, podług celów i wartości wyznaczonych przez konkretną sytuację i odpowiadające mu cielesne zaangażowanie, postać przeżywanego świata. W tej dialektyce wzajemnego współkształtowania to, w jakim ekspresyjnym stylu otwiera się na otoczenie intencjonalne ciało, decyduje o tym, jak wyrazi się przed nami owo otoczenie; i na odwrót. Ostateczny wynik tego wzajemnego stwarzania się zależy przede wszystkim od zdolności, jakie znajduje w swojej zmysłowej wrażliwości ucieleśniony percypient. Dlatego też nasze poznanie, zwieńczone przez wysłowione symbole, przez myślący język, swój zasadniczy charakter zawdzięcza przeżywanemu przez podmiot schematowi cielesnemu. Językowe znaczące nie odnoszą się do siebie wprost, lecz w cielesnym zapośredniczeniu. Znaczenia słów są w swej istocie rozwiniętymi ekspresjami gestykulującego ciała.

W nawet najbardziej abstrakcyjnych znaczeniach pulsuje zmysłowe unerwienie. Bez tego naturalnego symbolizmu ciała językowy symbolizm straciłby egzystencjalne oparcie - znaczące ześlizgiwałyby się na siebie w nieustannym bezsensie. Merleau-Ponty, przejmując od Saussure'a rozumienie języka jako systemu różnic, wbrew niemu twierdził, że językowa sygnifikacja wykracza poza same znaki - ich eskspresyjny Gestalt zawsze wyraża bezsłowną mowę gestu.

Jednakże Merleau-Ponty nie ustanawia tym samym jakiegoś karnalnego substancjonalizmu. Jedność ciała, o której mówi, jest żywa, dynamiczna, perspektywiczna i otwiera się nie na świat zastygłych w swojej uprzedniości

7 M. Merleau-Ponty Signs, przekład własny, Northwestern University Press, Evanston 1964, s. 88. 
przedmiotów, lecz intencjonalnie podejmuje motywy wyrosłe z fenomenalnego pola - niedookreślonego w swojej znaczeniowości.

Spójrzmy teraz przez chwilę w lustro Lacana. Niedojrzałe jeszcze do symbolicznej tożsamości dziecko dostrzega we własnym odbiciu obietnicę pełni, jego „ciało-w-kawałkach" ulega wizji wszechwładnego i kompletnego ucieleśnienia. Oddzielony od dopełniającej go matczynej zmysłowości, zyskuje nadzieję na przywrócenie wrażenia szczęśliwej omnipotencji i całkowitego usunięcia frustrującego braku dzięki przearanżowaniu swojej kruchej cielesności według zewnętrznego wzoru. Przeglądając się w obrazie idealnego ego, wyobcowuje się wprawdzie ze swojego realnie odczuwalnego istnienia, lecz bez poddania się tej iluzji nie przekroczy ono nigdy progu symbolicznie potwierdzonej egzystencji.

To libidalne obsadzenie lustrzanego refleksu jest więc nieuniknionym etapem w prawidłowym rozwoju podmiotu. Oczywiście, etapem wstępnym - jego agresywna natura, wpisana w dwójkową logikę wyobrażeniowej relacji, musi zostać zniesiona przez wprowadzenie trzeciego elementu, symbolicznego Ojca, który powściągnie przedwczesny triumf niedoszłego jeszcze podmiotu. To nie przypadek, że właśnie po identyfikacji ze zwierciadlaną iluzją panowania w dziecięcym organizmie wzmaga się dynamiczny rozwój mięśniowej koordynacji.

Ale i w samej już fazie lustra przez perspektywę porządku wyobrażeniowego prześwituje porządek symboliczny: narcystyczny zachwyt nie wystarczy; chcąc w pełni cieszyć się obrazem przyszłej autonomii i jedności, dziecko szuka akceptacji ze strony Innych, odwraca głowę od lustra w stronę dorosłych. Potrzebuje uznania ze strony wielkiego Innego. Tym zresztą odróżnia się od tych zwierząt, które również żywo reagują na własne odbicie, nie szukając jednak przy tym symbolicznego namaszczenia.

Wprawdzie ostateczna dojrzałość wiąże się dla Lacana z rozbiciem iluzji wyobrażeniowego idealnego ego, ale całkowita rezygnacja z prób osiągania jedności skazywałaby indywiduum na bezwładne i wyniszczające ześlizgiwanie się po przypadkowych łańcuchach znaczących. Na próżno szukalibyśmy tu jednak jakiejś drogi na skróty. I chociaż trzeba w końcu przejść na drugą stronę lustra i wyśliznąć się z duszących macek wyobrażeniowego ego, odciąć się od źródła agresywnego narcyzmu, to konstytucja podmiotu musi prowadzić przez alienacyjną formację ego. Później nadchodzi czas na powstrzymywanie tej wyobrażeniowej ekspansji.

Ważne jest jednak, by symboliczna interwencja miała na uwadze to, w jaki sposób próbuje wypowiedzieć nasze ciała współczesna kultura, co wmawia 
w naszą zmysłową samotożsamość symboliczne Nieświadome. W horyzontalnie rozprzestrzeniającej się gmatwaninie ponowoczesnych znaczeń i wartości tym bardziej należy przyjrzeć się hordzie Innych, wsłuchując się uważnie w ich hałaśliwe języki. Może być tak, że deklarowane przez nich symboliczne prawo służy za narzędzie do pogłębienia alienacji, tym skuteczniejszej, że ukrytej za zasłoną emancypacyjnej retoryki. Wróćmy teraz, jak zostało zapowiedziane, do "spastykującego" ciała. Ten typ korporalnej kontestacji polega na rozbijaniu ideologicznych obrazów ciała. Eksperymentowanie z ruchowymi, sensorycznymi, ekspresyjnymi możliwościami schematu cielesnego ma pozwalać na stawienie oporu symbolicznej przemocy ze strony społeczeństwa. Poddając swoje ciała nieobliczalnej motoryce niekontrolowanych odruchów, przedrzeźniając usankcjonowane znaczenia gestów, „spastykujący” doświadczają względności wymuszonych przez Innego inskrypcji i odsłaniają je we własnej ucieleśnionej egzystencji.

„Choć będące głównie pod kontrolą instytucji i przez nie przede wszystkim rozpowszechniane inskryptywne praktyki są jednak często parodiująco zniekształcane przez dzieci i tych, którzy, całkowicie lub częściowo, nie mają dostępu do kształtowanych przez te instytucje norm"8.

"Spastykujący” to z pewnością nie niewinne dzieci ani niekoniecznie ci, którzy są skazani na odcięcie od korzyści płynących z Systemu. Jak na filmie von Triera, zazwyczaj potrafią się nieźle, a niekiedy bardzo dobrze, w tymże Systemie urządzić. Wielu z nich dobrze zarabia, zajmując przy tym wysoką pozycję społeczną. „Dziecinnieją” dopiero w czasie wolnym od kariery i społecznych zobowiązań.

Nie zawsze przecież, jeśli w ogóle, potrzebujemy Ulrike Meinhof lub Czerwonych Brygad. Tragiczny czas i miejsce dla śmiertelnie poważnej Antygony rozgrywa się w zupełnie innych rejestrach. A „spastykujący” nie ukrywają swoich błazeńskich masek. Ich przedłużająca się z dnia na dzień zabawa na swój sposób poszerza granice codziennej, namacalnej swobody. Choć nad głowami tych prowokatorów nie łopoczą dumnie wzniesione sztandary wolności, ich rozprężone ciała wymykają się sztywnym, nadmiernie obsadzonym identyfikacjom - możliwość swobodnej autokreacji nie tylko jest przez nich myślana, ale i zmysłowo odczuwana. Dopóki „spastykowanie”, dzięki swojemu sprowokowanemu brakowi kontroli, wyślizguje się z jakiejkolwiek formy ideologicznego uścisku, pozostaje pożyteczną formą emancypacyjnej gimnastyki.

8 C. Noland Agency and Embodiment: Performing Gestures/Producing Culture, przekład własny, Harvard University Press, Cambridge, MA-London 2009, s. 214. 
Warto mieć też na uwadze to, że refleksyjne pogłębianie świadomości ciała nie jest wcale skazane wyłącznie na estetykę radykalnej transgresji i może służyć społecznej integracji tej, miejmy nadzieję, większości indywidualnych podmiotów, dla których odpowiedzialny samorozwój idzie w parze z troską o wzrost etycznej, intelektualnej i emocjonalnej jakości ogólnych relacji międzyludzkich. O możliwości, a nawet potrzebie wypracowania takiej estetyki tożsamości, która wyjdzie poza zbyt wąską i ekscentryczną perspektywę „estetyki egzystencji” à la Foucault i która, zamiast zajmować się Nietzscheańskim supermanem, nadaremnie krępując jego niezmożoną samowolę, zatroszczy się raczej o skromnego i ostrożnego everymana, nie bez powodzenia przekonuje od blisko trzydziestu już lat amerykański filozof Richard Shusterman.

Ten wybitny przedstawiciel współczesnego neopragmatyzmu, zainspirowany koncepcją "ciało-umysłu” Johna Deweya, fenomenologią ciała Maurice'a Merleau-Ponty'ego, a także praktycznymi osiągnięciami takich psychosomatycznych terapeutów jak Frederick Matthias Alexander i Moshe Feldenkrais, wbrew przeintelektualizownej filozofii analitycznej i przetekstualizowanej filozofii kontynentalnej, dowartościowuje w ramach wypracowanej przez siebie filozoficznej estetyki ciała niedyskursywną treść i formę „żywego doświadczenia”.

Jego somaestetyka „konotuje [...] zarówno poznawcze wyostrzanie naszej aisthesis czy percepcji sensorycznej, jak i pomysłowe przekształcanie formy naszego ciała i jego funkcjonowania; nie po to tylko, byśmy byli silniejsi i bardziej spostrzegawczy dla naszej własnej zmysłowej satysfakcji, ale byśmy stali się wrażliwsi na potrzeby innych i byli bardziej zdolni do odpowiadania na nie działaniami, które będą skutkiem naszej woli"

Podejmując meliorystyczny wysiłek Deweya, próbuje Shusterman „pogodzić" ze sobą intertekstualnie odcieleśnionych interpretatorów i zmysłowych świadków bezpośredniości, demaskując w ich antymetafizycznych deklaracjach skamieniałe pokłady metafizycznej w gruncie rzeczy logiki. Takie stanowisko skazywało go na polemikę także i z samymi neopragmatystami, którzy w przeważającej mierze skłonni są, co najwyżej, traktować ciało jako rzeczywistość drugiego rzędu. Zwrócił się on m.in. przeciwko Richardowi Rorty'emu, w jego rzekomym antyesencjalizmie dostrzegając „odwrócony esencjalizm", swoisty uniwersalizm tego, co indywidualne i przygodne,

9 R. Shusterman O sztuce i życiu. Od poetyki hip-hopu do filozofii somatycznej, przeł. W. Małecki, Atla 2, Wrocław 2007, s. 143. 
którego fałszywość ujawnia się właśnie w przebiegu codziennych cielesnych doświadczeń, zdolnych do efektywnego integrowania swych treści w dynamiczne, względnie trwałe i ogólne całości.

W filozoficznej replice wskazuje więc Shusterman na „istotną rolę ciała w rozstrzyganiu takich kwestii, jak zagadnienia epistemologiczne (poznanie zmysłowe, samoświadomość - poznanie swoich emocji poprzez obserwacje zachowania ciała), etyczne (ciało jako narzędzie realizacji naszej woli), socjopolityczne (ciało jako „uległy”, ,plastyczny” grunt dla represyjnej władzy społecznej) oraz ontologiczne ciało (ciało jako centralny punkt, z którego my sami i nasz światy wzajemnie się określają; ciało jako kryterium osobistej identyfikacji i jako ontologiczna podstawa dla wyjaśniania stanów mentalnych/system nerwowy)"10.

Trzeba też podkreślić, że twórca koncepcji somaestetyki nie ogranicza się do gołosłownego teoretyzowania, lecz, jak starożytny filozof grecki, ucieleśnia głoszone przez siebie nauki, dbając o swoją cielesno-umysłową kondycję. Korzysta przy tym z różnych psychosomatycznych technik, doświadczalnie sprawdzając ich praktyczną przydatność dla ugruntowywania i rozwijania tych indywidualnych postaw, które będą sprzyjać realizacji idei wolnego i satysfakcjonującego życia w demokratycznym społeczeństwie.

Choć Shusterman w pełni zgadza się z twierdzeniem Merleau-Ponty'ego, że to dzięki „swemu ciału rozumiem kogoś drugiego, tak samo jak dzięki swemu ciału spostrzegam " «rzeczy»"11, to jednak, w przeciwieństwie do francuskiego fenomenologa, nie ulega on pokusie somatycznego fundamentalizmu: ciało pozostawione same sobie, prędzej czy później, zawiedzie. Musi więc być ono nieustannie poddawane racjonalnie ułożonemu treningowi, a oprócz tego, co jakiś czas, także i zewnętrznej kontroli.

Rewaloryzacja spontanicznego charakteru naszej cielesności nie powinna zatem prowadzić do przeszacowania jej kognitywnych zdolności. Nie możemy bowiem całkowicie powierzyć naszego poznania somatycznym automatyzmom; zdarza się, że niezawodne zazwyczaj cielesno-doświadczeniowe nawyki z czasem wyrodnieją w źródło fałszywej wiedzy o świecie i nas samych. Stąd też niezbędne jest objęcie przeżywającego ciała refleksyjnym nadzorem, umożliwiającym skorygowanie zmysłowych wypaczeń i zaburzeń, których częstotliwość i intensywność narasta zwłaszcza teraz, gdy przyrodzone ciało

\footnotetext{
10 D. Koczanowicz Doświadczenie sztuki/sztuka życia. Wymiary estetyki pragmatycznej, Wydawnictwo Naukowe DSW, Wrocław 2008, s. 164.

11 M. Merleau-Ponty Proza świata. Eseje o mowie, przeł. S. Cichowicz i inni, Warszawa 1999, s. 97.
} 
współczesnego człowieka przeistacza się w wirze cyfrowych, wirtualnych światów.

Ważne, by tej wyzwalającej somaestetycznej gry nie nawiedził duch „zwierzęcej powagi". Jeśli bowiem jedynym jej celem jest estetyczne wychowanie człowieka ku dojrzalszej wolności, niech życzliwa ironia nie przestanie nigdy być jej arbitrem i reżyserem. Między skrajną wersją perwersji, Ojcem, który nigdy nie zaczyna mówić, a psychotycznym wykluczeniem Ojca, rozciąga się rozległa konstelacja żywych symboli, których perspektywy przenikają się w zmiennych ucieleśnieniach.

Wybór określonej metody pracy nad świadomością ciała powinien być zatem dokonywany w ramach, mniej lub bardziej, doraźnie zarysowanego aksjologicznego projektu, projektu, w którego tymczasowość wpisana jest zmienna dynamika życia. Dane dzieło sztuki, dana technika somaestetyczna nie mogą być nigdy oceniane jako cele same w sobie, lecz zawsze ze względu na ich utylitarność.

Gdy podczas rewolucji kulturalnej w Chinach na indeks zakazanych dzieł trafiają m.in. utwory Schuberta, to pragmatyczna logika tej anatemy jest prawidłowa: muzyczne rozterki romantycznego kompozytora z pewnością utrudniałaby maoistycznym indoktrynerom tresurę ideologicznie użytecznych ciał. Równie racjonalna jest dzisiejsza postawa chińskiej partii komunistycznej wobec "sekty" Falun Gong - walka o ciała jest niczym innym, jak walką o rząd dusz. Dokładnie taką samą logikę odnajdujemy w somaestetyce Shustermana; tym, co ją natomiast diametralnie odróżnia od totalitarnej estetyki cielesnego wywłaszczania, są zgoła odmienne cele, spośród których do najważniejszych należy wspieranie tych teorii i praktyk psychosomatycznych, które przyczyniają się do umacniania wzajemnej relacji między wolnym i szczęśliwym podmiotem i jego demokratycznym środowiskiem społecznym.

Amerykański filozof, choć sam propaguje konkretny rodzaj treningu cielesnego, metodę Feldenkraisa, a estetycznego modelu dla masowego rozwoju świadomości ciała upatruje przede wszystkim w subkulturze hip-ho$\mathrm{pu}$, to wierny swoim emancypacyjnym zamiarom, zachęca do sprawdzania także innych metod cielesnego treningu i do doświadczania różnych form estetycznych.

W nawiązaniu do muzycznych upodobań Shustermana warto tu wspomnieć o Danielu Sapenie, który także odwołując się do liberalnych ideałów, wskazuje przy tym na inny estetyczny wzorzec. W napisanej niedawno książce Freud's Lost Chord: Discovering Jazz in the Resonant Psyche, odnosząc się do swojej psychoanalitycznej praktyki, a także do swoich muzycznych, na 
wpół profesjonalnych, doświadczeń, kreśli w niej analogię między muzyczną strukturą jazzu i właściwą strukturą procesu psychoanalitycznego. Jazz jest dla niego formą estetycznego wychowania, a także modelem prawidłowych relacji interpersonalnych.

Według Sapena sztuka, a zwłaszcza muzyka, podejmując nierówny rytm naszych ciał, niepewne i rozproszone frazy zmiennych emocji, progresywnie zestraja je w harmonijną całość, w której własne jestestwo możemy odczuć jako rozwijającą się w czasie i przestrzeni kompozycję, retroaktywnie rozwiązującą wewnętrzne konflikty i napięcia. Ta psychosomatycznie przeżyta wiedza o strukturalnie pożytecznej roli tego, co w odosobnieniu od całości, jawi się jako fragmentaryczna i szkodliwa nieswojość, ma stanowić skuteczną przesłankę dla empatycznego otwarcia się na to, co w nas samych i na zewnętrz nas odczuwamy jako zagrażające Inne. W „całym tym zgiełku”, „w tym szaleństwie”, jakim wydaje się niekiedy nasza egzystencja, Sapen wskazuje nie bez powodów na jazz jako skuteczną metodę na wzajemne oddziaływanie z fizycznym i międzypodmiotowym otoczeniem.

Tej muzyki, nastrajającej się w procesie swobodnego stawania, nie należy mylić z terapią muzyczną, ale i też samej analizy nie powinno się postrzegać jako pewnego „rodzaju koncertu jazzowego”, pod tym względem zarzuty niektórych moich kolegów są więc całkowicie na wyrost. Niemniej, trzeba przyznać, że to właśnie w tak ukształtowanej muzyce analiza znajduje wyjątkowo skuteczne wsparcie dla swoich zasadniczych celów i wartości. Przez wiele lat miałem już wystarczająco dużo okazji, aby przekonać się jak rozmaite wydarzenia muzyczne - np. oparte na strumieniu świadomości fortepianowe koncerty Keitha Jarretta, nagrania Milesa Davisa z okresu Bitches Brew czy nasycone tęsknym, zadumanym tonem poematy Jana Garbarka i Ralpha Townera - mogą dostarczyć wiarygodnego akompaniamentu dla twórczej i refleksyjnej pracy i to niezależnie od przyjemności płynącej z uważnego ich wysłuchania. Mimo ich intensywności, sprzyjają one precyzyjnemu i kreatywnemu myśleniu, zapewne dzięki temu, że potrafią stworzyć przestrzeń, w której afekt i forma, wolność i dyscyplina, wzburzenie i bezruch wywołują atmosferę takiego akustycznego środowiska, w którym można się poczuć, jak u siebie, w pełni odzwierciedlonym, ośmielonym i zawezwanym. Takie utwory synchronizują moją psychocielesność, nastrajają mój mózg. Tak brzmiąca muzyka, działając podobnie do analizy, integruje osobowość [...], zapewniając świadomości i nieświadomości znacznie dogodniejsze warunki 
dla płynnej wymiany, w tajemniczy sposób kreując przestrzeń przypominającą to środowisko wsparcia, w którym dziecko lub pacjent rozwija swoje zdolności do przemyśliwania i zamieszkiwania własnego ciała. ${ }^{12}$

Ciało i słowo to dwa skierowane ku sobie nurty, przenikające się w hermeneutycznym kole egzystencji, wciąż poruszane nowym doznaniem, nową interpretacją, nigdy do końca tożsame, choć zawsze splecione w ruchu nieustannie odradzającego się życia. Bez ciała słowo staje się martwą literą. Bez słowa ciało rozpada się na nic nieznaczące kawałki. Zapewne dlatego jesteśmy dziś, w epoce narastającego nonsensu, świadkami i podmiotami rozpaczliwych i nieudolnych prób ponownego ucieleśnienia na zawsze utraconych znaczeń. Dlatego współczesny człowiek tak chętnie opisuje swoje nieszczelne ciało potwierdzającą jego tożsamość pieczęcią tatuażu lub poddaje swoją zmysłowość irracjonalnym eksperymentom, jakby spodziewał się, że w bezmyślności afektu odczuje to, kim naprawdę jest.

Wyrażona przeze mnie nieufność bynajmniej nie ma na celu zdyskredytowania wszelkich prób zwiększenia somatycznej świadomości. Rzecz w tym, by każda z tych cielesnych praktyk potrafiła teoretycznie określić jakość i zasięg spodziewanych rezultatów. Chciałoby się wiedzieć, komu i w imię czego mają one służyć.

Zbyt często bowiem rozbudzanie świadomości ciała przybiera formę kultu „przeżycia dla samego przeżycia”, w którym rzekome poznanie samego siebie degraduje się łatwo do rzędu narcystycznego samouwielbienia. Pytani o ich przeżycia, zarówno uczniowie, jak i ich mistrzowie wygłaszają nieprzejrzyste frazesy o wyzwoleniu i niedającej się ująć w słowa samowiedzy. I właśnie ta ich naga, nieubrana samowiedza uśmiecha się dość fałszywie, niczym plastikowy Budda do naiwnych, wiecznych turystów.

Strzeżmy się więc niewymownych czcicieli ciała. „Według Kristevej utrata znaczenia oddziałuje afektywnie na podmiotowość w formie rozpaczy i/ lub gwałtownej przemocy"13. Dopuśćmy do głosu oświeconych specjalistów: fizjoterapeutów, psychoterapeutów, psychoanalityków, filozofów i innych, nauczonych krytycznego myślenia. Dopiero po spełnieniu tego warunku psychosomatyczne praktyki zyskają na wiarygodności.

D. Sapen Freud's Lost Chord: Discovering Jazz in the Resonant Psyche, przekład własny, Karnac Books, London 2012, s. 174. 
Dzięki przywoływanym w tym tekście, tak różnym skądinąd myślicielom, jak Kristeva, Merleau-Ponty i Lacan (choć ten ostatni w ograniczonym zakresie, dotyczącym głównie jego późnej, skoncentrowanej wokół popędów, twórczości) mogliśmy przekonać się o tym, że symboliczny język jest ekspresją przeżywanego ciała, jego emanacją, która powraca do cielesnych źródeł jako wezbrana fala refleksyjnego światła, pogłębiającego rozumienie świata i siebie samego. Wobec tego, ten, który mówi o niemożliwości wyrażenia swoich doznań somatycznych, zaprzecza tym artystom i myślicielom estetycznego logosu, których słowa i znaczące gesty budzą w naszych ciałach drżenie, naszym niepewnym myślom przywracając odczuwalną, żywą postać.

Konfesyjność ciała, czy to w postaci intymnego spotkania ze sztuką, czy też jako równie przejmujące wyznanie najgłębszych zmysłowych przeżyć, w pełni komunijnego charakteru nabiera dopiero we wspólnocie języka; w słownych gestach cielesna ekspresja zamienia się w poszerzający naszą somaestetyczną świadomość dialog z nieznanym dotąd samym sobą albo z kimś Drugim.

Chociaż między ciałem a językiem zawsze pozostaje refleksyjny odstęp i obie strony egzystencji nigdy nie zbiegają się ze sobą do końca, to przecież ciągle słyszymy, jak w jednych słowach głucho, a w innych dźwięcznie rozbrzmiewa to, co odczuwalne. Dzieje się tak dlatego, że estetyczny język, w którym nasze ciało mówi o sobie, nie jest zewnętrznym wobec niego przestawieniem, lecz jego ekspresją, jakby to ujął Hans Georg Gadamer - nie reprezentacją, a prezentacją, uobecnieniem.

Tak często doświadczamy takich estetycznych prób wysłowienia cielesnego logosu, że na koniec niniejszych rozważań chciałbym przywołać znacznie bardziej spektakularny i wymowny niż nasze codzienne z tą materią zmagania przykład Dostojewskiego i jego wytrwałych poszukiwań „nowego słowa”: można by rzec, że cała jego jurodiwa, rozgorączkowana, konwulsyjna i porywająca literatura była w pewnym sensie symboliczną odpowiedzią, jaką dawał własnemu ciału, odpowiedzią na epileptyczną chwilę ekstazy i następującego po niej mrocznego otępienia.

Nie jest tak, że wypływająca z samej istoty rzeczywistości niepełność, prowizoryczność i perspektywiczność interpretacji cielesnych przeżyć zwalnia nas z konieczności jej nieustannego podejmowania. Jeśli odczuwamy potrzebę psychosomatycznego udoskonalenia, musimy przecież wpierw wyraźnie ustalić jego możliwe kierunki i zasadnicze motywy. Zanurzenie się w samej tylko zmysłowej ekscytacji to pójście na dno anonimowego Bytu, gdzie to już nie my odczuwamy, tylko Coś odczuwa naszą śmierć. 


\section{Abstract}

\section{Robert Dobrowolski}

UNIVERSITY SCHOOL OF PHYSICAL EDUCATION IN WROCLAW (AWF)

The Somaesthetics of Identity: Between the Body and the Word

There is no doubt that the modern revaluation of carnality has helped advance both social and individual emancipation. However, an intense focus on the body also involves processes that lead to the exact opposite effect, namely a profound, 'subcutaneous' enslavement. This is especially the case when the awakening of body awareness takes the form of a cult of 'experience for experience's sake,' in which the alleged goal of selfknowledge easily degrades into narcissistic self-glorification. Dobrowolski calls for caution, especially when facing individuals who use the essential unrepresentability of bodily sensations as a veil, as they are not willing or unable to subject their experiences to a honest and thought-through analysis founded in a solid theoretical context.

\section{Keywords}

body, aesthetic logos, language, expression, interpretation 